\title{
PENERAPAN MODEL PEMBELAJARAN ARIAS (ASSURANCE, RELEVANCE, INTEREST, ASSESSMENT, AND SATISFACTION) UNTUK MENINGKATKAN AKTIVITAS SISWA DAN HASIL BELAJAR MATEMATIKA
}

\author{
Nur Ismiyati \\ Universitas Balikpapan \\ pos-el : nurismiyati@uniba-bpn.ac.id
}

\begin{abstract}
ABSTRAK
Penelitian ini adalah penelitian tindakan kelas bertujuan untuk memperbaiki pembelajaran matematika di kelas VIII SMP Negeri 1 Bontonompo melalui model pembelajaran ARIAS (Assurance, Relevance, Interest, Assesment, and Satisfaction). Masalah dalam penelitian ini adalah kurang dari $75 \%$ siswa memiliki hasil belajar matematika di bawah nilai KKM dan aktivitas siswa dalam proses belajar yang masih kurang. Penelitian dilaksanakan selama dua siklus. Data diperoleh secara kualitatif dan kuantitatif. Berdasarkan hasil penelitian pada Siklus I diperoleh data hanya $26 \%$ siswa yang memenuhi nilai KKM sehinggga dilanjutkan ke Siklus II dan hasilnya memenuhi ketuntasan individu maupun klasikal yaitu 78\% siswa memenuhi nilai KKM dan aktivitas siswa mengalami peningkatan.
\end{abstract}

Kata kunci : model pembelajaran ARIAS, aktivitas, hasil belajar

\section{ABSTRACT}

This research is a classroom action research that aims to improve mathematics learning in class VIII Junior High School 1 at Bontonompo through the ARIAS learning model. The problem in this research are less than $75 \%$ of students have mathematics learning under KKM and students less learning activities. The research was carried out during two cycles. The obtained data were analyzed qualitatively and quantitatively. Based on the results of the research in Cycle I, only $26 \%$ of students fulfilled the KKM value were continued to Cycle II and the results met individual and classical completeness is $78 \%$ of students fulfilled KKM scores and student activities increased.

Keywords : ARIAS learning model, activity, learning outcomes

\section{PENDAHULUAN}

Matematika berasal dari kata Yunani "mathein" atau "manthenein", yang artinya "mempelajari". Kata tersebut erat hubungannya dengan kata Sanskerta "medha" atau "widya" yang artinya "kepandaian", "ketahuan", atau "intelegensi" (Masykur \& Abdul Halim, 2009).

Proses belajar matematika tidak hanya sekadar menerima informasi, mengingat dan mengafal. Siswa harus bekerja untuk memecahkan masalah dan menemukan ide-ide agar siswa dapat memahami dan dapat menerapkan ilmu pengetahuan serta mampu mengimplementasikan dalam kehidupan sehari-hari. Menurut Ruseffendi ET (Suerman et al., 2003) Matematika terbentuk sebagai hasil pemikiran manusia yang berhubungan dengan ide, proses dan penalaran. Guru harus dapat memilih strategi yang tepat untuk dapat mengaktifkan siswa dalam proses 
pembelajaran, agar terdapat perubahan pada diri siswa dalam kegiatan belajar.

Berdasarkan observasi awal pada pembelajaran matematika di SMP Negeri 1 Bontonompo dengan melakukan wawancara dengan guru bidang studi matematika ditemukan keragaman masalah, yakni tentang rendahnya aktivitas siswa dalam mengikuti pembelajaran matematika ketika diberikan kesempatan untuk bertanya tidak lebih dari 2 orang yang mengajukan tangan untuk bertanya, kurangnya keberanian siswa untuk mengerjakan soal di depan kelas, siswa kurang aktif dalam berdiskusi di dalam kelas, adanya siswa yang tidak dapat mengikuti pelajaran dengan baik, kurangnya persiapan siswa dalam mengikuti pelajaran, sebagian siswa tidak membawa peralatan belajar matematika yang lengkap sehingga siswa meminjam peralatan alat tulis kepada temannya, siswa pasif dalam proses pembelajaran. Hanya beberapa siswa yang mau memperhatikan penjelasan guru, mencatat materi pelajaran, bertanya pada guru bila ada kesulitan dan mau menjawab soal di depan kelas. Kurangnya pengimplementasian terhadap materi matematika dengan kejadian-kejadian nyata di sekeliling siswa sehingga berakibat pada hasil belajar siswa yang masih rendah. Beberapa penyebab rendahnya hasil belajar di kelas tersebut diantaranya adanya kesalahan-kesalahan yang dilakukan oleh siswa itu sendiri. Salah satu kesalahan yang dimaksud adalah kesalahan konsep yang terkadang dilakukan oleh siswa sehingga mereka mengalami kesulitan bahkan tidak dapat menyelesaikan soal yang diberikan. Kelalaian siswa dalam belajar menjadi penyebab utama timbulnya kesalahan-kesalahan tersebut.

Selain itu, ketercapaian hasil belajar matematika terhadap KKM yang telah ditetapkan yaitu tuntas apabila telah mencapai minimal $72 \%$ siswa telah mendapat nilai $\geq 72$. Berdasarkan hasil ulangan semester ganjil tahun ajaran 2015/2016 diketahui bahwa dari 27 siswa kelas VIII tidak ada satupun siswa yang mencapai nilai KKM.

Menurut

Reigulth

(Suprihatingrum, 2013) berpendapat bahwa hasil belajar atau pembelajaran dapat juga dipakai sebagai pengaruh yang memberikan suatu ukuran nilai dari metode (strategi) alternative dalam kondisi yang berbeda.

Selain itu, siswa mengatakan bahwa saat belajar matematika dan harus mengikuti pelajaran matematika ternyata menganggap bahwa matematika merupakan pelajaran yang sulit dan tekadang menjadi pelajaran yang menakutkan dan tidak menjadi hal menarik bagi sebagian besar siswa, minat siswa terhadap pelajaran matematika siswa begitu rendah membuat interaksi belajar mengajar di kelas menjadi begitu kaku atau monoton sehingga sebagian besar kegiatan di kelas didominasi guru. Paradigma di dalam pikiran siswa bahwa matematika itu sulit membuat siswa tidak begitu tertarik untuk mengikuti kelas matematika dengan baik. Paradigma ini dapat menyebabkan rendahnya kepercayaan diri siswa terhadap kemampuan yang dimiliki sehingga membuat pelajaran matematika semakin menakutkan. Akibat dari percaya diri rendah, siswa tidak memiliki minat untuk mengikuti proses pembelajaran dengan baik saat mereka belajar di 
kelas. Minat rendah siswa merupakan bagian dari penolakan untuk terlibat dalam proses pembelajaran di kelas. Hal ini menunjukkan bahwa aktivitas siswa dan hasil belajar siswa dalam proses pembelajaran masih relatif rendah.

Untuk menyikapi hal tersebut perlu adanya suatu tindakan agar aktivitas dan hasil belajar matematika siswa meningkat. Oleh karena itu, sebaiknya guru berupaya agar mampu menciptakan suasana pembelajaran yang dapat meningkatkan aktivitas pembelajaran siswa dengan baik.

Berkenaan dengan hal itu, maka dengan memperhatikan berbagai konsep dan teori belajar dikembangkanlah suatu model pembelajaran yang disebut dengan pembelajaran ARIAS yang dikembangkan oleh Keller dan Koop (Rahman \& Amri, 2014) sebagai upaya merancang pembelajaran yang dapat mempengaruhi motivasi berprestasi dan hasil belajar.

Berdasarkan latar belakang di atas peneliti ingin mengetahui sejauh mana model pembelajaran ARIAS dapat membantu siswa dalam meningkatkan aktivitas dan hasil belajar siswa yang akan dikaji melalui Penelitian Tindakan Kelas (PTK) yang berjudul "Penerapan Model Pembelajaran ARIAS (Assurance, Relevance, Interest, Assessment, dan Satisfaction) untuk meningkatkan aktivitas dan hasil belajar matematika siswa".

Penggunaan model pembelajaran ARIAS perlu dilakukan sejak awal, sebelum guru melakukan kegiatan pembelajaran di kelas. Model pembelajaran ini digunakan sejak guru merancang kegiatan pembelajaran dalam bentu satuan pelajaran. Satuan pelajaran sebagai pegangan (pedoman) guru kelas dan satuan pelajaran sebagai bahan/materi bagi siswa. Satuan pelajaran sebagai pegangan bagi guru disusun sedemikian rupa sehingga satuan pelajaran tersebut sudah mengandung komponen-komponen ARIAS. Artinya, dalam satuan pelajaran itu sudah tergambarkan usaha/kegiatan yang akan dilakukan untuk menanamkan rasa percaya diri pada siswa, mengadakan kegiatan yang relevan, membangkitkan minat/perhatian siswa, melakukan evaluasi dan menumbuhkan rasa dihargai/bangga pada siswa. Guru atau pengembang sudah merancang urutan semua kegiatan yang akan dilakukan, strategi atau metode pembelajaran yang akan digunakan, media pembelajaran apa yang akan dipakai, perlengkapan apa yang dibutuhkan, dan bagaimana cara penilaian akan dilaksanakan. Meskipun demikian pelaksanaan kegiatan pembelajaran disesuaikan dengan situasi, kondisi dan lingkungan siswa (Rahman \& Amri, 2014).

Penelitian dari Prahesti Sthyawati (Sthyawati, 2011) yang berjudul "Penerapan Model Pembelajaran ARIAS (Assurance, Relevance, Interest, Assessment, san Satisfaction) untuk Meningkatkan Aktivitas Belajar Matematika Siswa", hasil penelitiannya menunjukkan bahwa adanya peningkatan dari tiap siklusnya. Hal ini terbukti dari nilai rata-rata aktivitas belajar siswa tiap siklusnya yaitu pada siklus I sebesar 2,97 dengan aktivitas kategori cukup, siklus II sebesar 3,55 dengan aktivitas dalam kategori baik dan pada siklus III meningkat menjadi 4,26 dengan aktivitas dalam kategori sangat baik. Berdasarkan penelitian tesebut bahwa penerapan model 
pembelajaran ARIAS dapat meningkatkan aktivitas dan hasil belajar matematika siswa kelas VII-1 MTs. Sa'adatul Mahabbah Pondok Cabe Udik.

\section{METODE PENELITIAN}

Jenis penelitian ini adalah Penelitian Tindakan Kelas (Classroom Action Research) dengan pelaksanaan kolaboratif antara peneliti sebagai pengamat (observer) dan guru mata pelajaran Matematika yang bertindak sebagai pelaku/pelaksana. Penelitian dilaksanakan pada semester genap tahun ajaran 2015/2016. Subjek dalam penelitian ini adalah siswa kelas VIII A SMP Negeri 1 Bontonompo. Objek dalam penelitian ini yaitu aktivitas belajar dan hasil belajar siswa pada mata pelajaran Matematika untuk melihat peningkatan aktivitas siswa dan hasil belajar matematika siswa melalui penerapan model pembelajaran ARIAS. Pelaksanaan penelitian tindakan kelas ini dilakukan 2 siklus. Siklus I dilaksanakan selama 3 minggu (5 kali pertemuan) dan Siklus II dilaksanakan selama 2 minggu (4 kali pertemuan). Perencanaan jumlah pertemuan ini berdasarkan kompetensi dasar dan indikator pencapaian kompetensi dari materi yang akan diajarkan yaitu lingkaran. Hasil tindakan pada tiap siklus dianalisis melalui empat tahapan yakni perencanaan, tindakan, observasi, refleksi sehingga berdasarkan analisis tersebutlah maka dapat ditentukan apakan siklus selanjutnya dapat dilanjutkan atau tidak.

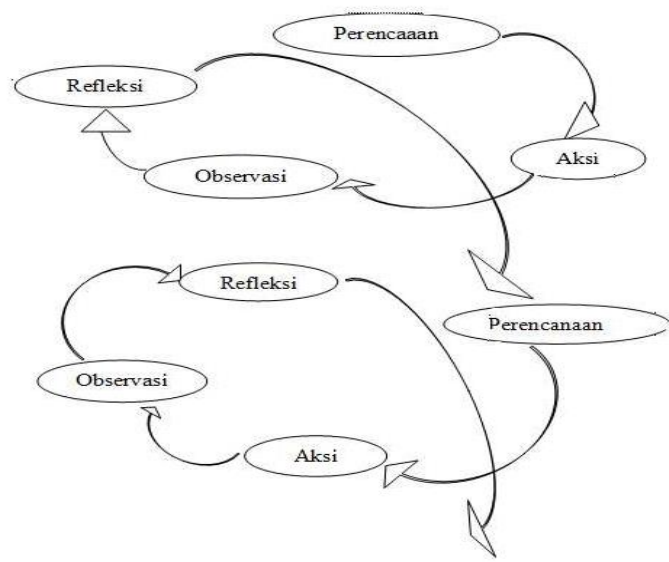

Gambar 1. Model Spiral Tindakan Kelas dari Kemmis dan Taggart yang dimodifikasi (Wiriaatmadja, 2006)

Instrumen yang digunakan dalam penelitian ini adalah lembar observasi, lembar keterlaksanaan model pembelajaran, angket, dan tes hasil belajar.

Teknik pengumpulan data dalam penelitian ini yakni data tentang aktivitas siswa, aktivitas guru, suasana kelas dalam proses pembelajaran, dan keterlaksanaan model pembelajaran dengan penerapan model pembelajaran ARIAS (Assurance, Relevance, Interest, Assessment, dan Satisfaction) yang dilakukan dengan menggunakan lembar observasi. Data tentang Assurance, Interest dan Satisfaction diperoleh melalui pemberian angket di setiap akhir siklus. Data tentang hasil belajar siswa yang diperoleh melalui pemberian tes pada siswa di setiap akhir siklus.

Teknik analisis data yang digunakan adalah pada hasil belajar batas ketuntasan dikelompokkan menjadi dua kategori, yaitu tuntas dan tidak tuntas berdasarkan Kriteria Ketuntasan Minimal (KKM) mata pelajaran matematika kelas VIII SMP Negeri 1 Bontonompo. 
Tabel 1. Kriteria Kelulusan

\begin{tabular}{|c|c|c|}
\hline \multicolumn{2}{|c|}{ Kriteria Kelulusan } & \multirow{2}{*}{ Kualifikasi } \\
\cline { 1 - 2 } Individu & Klasikal & \\
\hline$\geq 72$ & $\geq 75 \%$ & Tuntas \\
\hline$<72$ & $<75 \%$ & Tidak Tuntas \\
\hline
\end{tabular}

Ketuntasan klasikal disajikan dalam bentuk presentase dengan rumus:

$$
x=\frac{\sum \text { siswa yang tuntas belajar }}{\sum \text { siswa }} \times 100 \%
$$

(Aqib dalam Iskandar, 2013:94)

Rata-rata hasil belajar dengan rumus:

$$
\bar{X}=\frac{\sum X}{\sum N}
$$

Keterangan:

$\bar{X} \quad=$ Nilai rata-rata

$\sum X=$ Jumlah semua nilai siswa

$\sum N=$ Jumlah siswa

Analisis keterlaksanaan model pembelajaran disajikan dalam bentuk persentasi dengan rumus:

$$
\% K M P=\frac{P}{N} \times 100 \%
$$

Keterangan:

$$
\begin{aligned}
\% \mathrm{KMP}= & \text { Persentase Keterlaksanaan } \\
& \text { Model Pembelajaran } \\
\mathrm{P}= & \text { Jumlah Check-List (Ya) pada } \\
& \text { tahap pembelajaran } \\
\mathrm{N}= & \text { Jumlah Keseluruhan tahap } \\
& \text { pembelajaran }
\end{aligned}
$$

Tabel 2. Kriteria Keterlaksanaan Model

\begin{tabular}{|c|c|c|}
\multicolumn{3}{|c}{ Pembelajaran } \\
No. & $\begin{array}{c}\text { Kategori } \\
\text { Keterlaksanaan } \\
\text { Model } \\
\text { Pembelajaran }(\%)\end{array}$ & Interpretasi \\
\hline 1. & $0,0-24,9$ & Sangat Kurang \\
\hline 2. & $25,0-37,5$ & Kurang \\
\hline 3. & $37,6-62,5$ & Sedang \\
\hline 4. & $62,6-87,5$ & Baik \\
\hline 5. & $87,6-100$ & Sangat Baik \\
\hline
\end{tabular}

Sumber: Nuh (Hendriyani, 2010)
Analisis data hasil angket disajikan dalam bentuk persentase dengan rumus :

$R=\left(\frac{\text { umlah skor yang diperoleh seluruh siswa }}{\text { Banyaknya siswa } \times \text { skor maksimum }}\right) \times 100 \%$

Tabel 3. Klasifikasi Angket Assurance, Interest, dan Satisfaction

\begin{tabular}{|c|c|}
\hline $\begin{array}{c}\text { Skor yang diperoleh dalam } \\
\text { persentase }\end{array}$ & Kategori \\
\hline $0 \%-33,33 \%$ & Rendah \\
\hline $33,34 \%-66,67 \%$ & Sedang \\
\hline $66,68 \%-100 \%$ & Tinggi \\
\hline
\end{tabular}

(Sumber: Purwanto dalam Hasriana, 2012)

Berdasarkan klasifikasi diatas, aspek Assurance, Interest dan Satisfaction dikatakan terpenuhi untuk setiap siklus jika minimal 19 orang siswa berada pada kategori tinggi.

\section{HASIL DAN PEMBAHASAN}

1) Deskripsi Pelaksanaan Tindakan Siklus I

Pada tahap perencanaan pelaksanaan tindakan peneliti telah menelaah beberapa hal berkaitan penelitian diantaranya kurikulum, materi pembelajaran matematika. Setelah itu peneliti membuat RPP dengan model pembelajaran ARIAS yang menjadi pedoman peneliti dalam melaksanakan pembelajaran dikelas. Selanjutnya, peneliti menggunakan buku paket dan membuat LKS. Pada bagian akhir Siklus I, peneliti menganalisis dan menyeleksi soal-soal yang akan diberikan kepada siswa setelah pembelajaran dengan menggunakan model pembelajaran ARIAS. Analisis dan seleksi soal ini menghasilkan kisi-kisi tes hasil belajar Siklus I. Selanjutnya, pemberian angket yang digunakan untuk mengukur percaya diri (Assurance), minat 
(Interest) dan penguatan (Satisfaction) pada siswa.

Hasil tes siklus I siswa kelas VIIIA SMP Negeri 1 Bontonompo dianalisis secara deskriptif sebagai berikut:

$$
\bar{x}=\frac{\sum_{i=1}^{n} x_{i}}{n}=\frac{1476}{27}=54,67
$$

Tabel 4. Statistik Skor Hasil Belajar Matematika Siswa Kelas VIIIA SMP Negeri 1 Bontonompo pada Siklus I

\begin{tabular}{|c|c|c|}
\hline No. & STATISTIK & $\begin{array}{c}\text { NILAI } \\
\text { STATISTIK }\end{array}$ \\
\hline 1 & Subjek Penelitian & 27 \\
2 & Skor Ideal & 100 \\
3 & Skor Maksimum & 96 \\
4 & Skor Minimum & 32 \\
5 & Rentang Skor & 64 \\
6 & Skor Rata-rata & 54,67 \\
7 & Standar Deviasi & 17,526 \\
\hline
\end{tabular}

Tabel 4. menunjukkan bahwa skor rata-rata kemampuan siswa dalam pelajaran matematika, setelah diterapkan pembelajaran dengan model ARIAS yang diperoleh pada siklus I adalah rata-rata 54,67 dari skor ideal yang mungkin tercapai 100. Secara individual skor yang dicapai siswa dari skor terendah 32 sampai skor tertinggi 96 dengan skor yang mungkin tercapai dari 0 sampai 100.

Skor hasil tes dikategorikan berdasarkan ketuntasan belajar siswa pada tes akhir siklus I sebagai berikut:

Tabel 5. Deskripsi Ketuntasan Belajar Matematika Siswa Kelas VIIIA SMP Negeri 1 Bontonompo pada Tes Siklus I

\begin{tabular}{|c|c|c|c|}
\hline Skor & Kategori & Frekuensi & $\begin{array}{c}\text { Persentase } \\
(\%)\end{array}$ \\
\hline $0-71$ & $\begin{array}{c}\text { Tidak } \\
\text { Tuntas }\end{array}$ & 20 & 74 \\
\hline $72-100$ & Tuntas & 7 & 26 \\
\hline \multicolumn{2}{|c|}{ Jumlah } & 27 & 100 \\
\hline
\end{tabular}

Tabel 5. menunjukkan bahwa $74 \%$ atau 20 siswa termasuk dalam kategori belum tuntas dan $26 \%$ atau 7 orang dalam kategori tuntas. Jika dianalisis sesuai indikator keberhasilan tindakan untuk skor hasil belajar, pada siklus I skor hasil belajar belum mencapai ketuntasan baik secara individual maupun klasikal. Karena skor hasil belajar siswa pada siklus I yang berada di atas nilai KKM atau dalam kategori TUNTAS kurang dari $75 \%$ yakni $26 \%$.

Keterlaksanaan pembelajaran yang diobservasi adalah aktivitas guru dalam mengelola pembelajaran dengan menerapkan model pembelajaran ARIAS yang mengacu pada RPP sebagai berikut:

Tabel 6. Persentase Keterlaksanaan Model Pembelajaran ARIAS

\begin{tabular}{|c|c|c|c|}
\hline $\begin{array}{c}\text { Pertemuan } \\
\text { Ke- }\end{array}$ & Nilai & $\begin{array}{c}\text { Persentase } \\
(\mathbf{\%})\end{array}$ & Kriteria \\
\hline $\mathbf{1}$ & 13 & 92,31 & Sangat Baik \\
\hline $\mathbf{2}$ & 13 & 100 & Sangat Baik \\
\hline $\mathbf{3}$ & 13 & 100 & Sangat Baik \\
\hline $\mathbf{4}$ & 13 & 100 & Sangat Baik \\
\hline
\end{tabular}

Tabel 6. di atas secara keseluruhan pembelajaran dengan menggunakan model pembelajaran ARIAS berada pada kriteria sangat baik pada pertemuan pertama hingga keempat. Berdasarkan hal tersebut, maka dapat disimpulkan bahwa proses pembelajaran yang dilaksanakan pada kelas yang diajar dengan menerapkan model pembelajaran ARIAS terlaksana dan berada pada kategori sangat baik yang sesuai dengan RPP.

Analisis angket percaya diri (Assurance) siswa pada siklus I dengan menggunakan skala Likert sebagai berikut : 
Tabel 7. Distribusi Frekuensi dan Persentase

Angket Percaya Diri (Assurance)

\begin{tabular}{|c|l|c|c|}
\hline Skor dalam \% & Kategori & $\mathrm{f}$ & Persentase (\%) \\
\hline $0 \%-33,33 \%$ & Rendah & 0 & $0 \%$ \\
$33,34 \%-66,67 \%$ & Sedang & 2 & $7,41 \%$ \\
$66,68 \%-100 \%$ & Tinggi & 25 & $92,59 \%$ \\
\hline \multicolumn{2}{|c|}{ Jumlah } & 27 & 100 \\
\hline
\end{tabular}

Berdasarkan Tabel 7. dapat disimpulkan bahwa dari 27 orang siswa yang menjadi subjek penelitian $7,41 \%$ atau 2 siswa yang percaya dirinya berada pada ketegori "Sedang", 92,59\% atau 25 siswa yang percaya dirinya berada pada kategori "Tinggi", dan tidak terdapat siswa yang berada pada kategori "Rendah".

Analisis angket minat (Interest) siswa pada siklus I dengan menggunakan skala Likert sebagai berikut :

Tabel 8. Distribusi Frekuensi dan Persentase Angket Minat (Interest)

\begin{tabular}{|c|c|c|c|}
\hline Skor dalam \% & Kategori & Frekuensi & $\begin{array}{c}\text { Persentase } \\
(\%)\end{array}$ \\
\hline $0 \%-33,33 \%$ & Rendah & 0 & $0 \%$ \\
\hline $33,34 \%-66,67 \%$ & Sedang & 6 & $22,22 \%$ \\
\hline $66,68 \%-100 \%$ & Tinggi & 21 & $77,78 \%$ \\
\hline \multicolumn{2}{|l|}{ Jumlah } & 27 & 100 \\
\hline
\end{tabular}
disimpulkan bahwa dari 27 orang siswa yang menjadi subjek penelitian $22,22 \%$ atau 6 siswa yang minatnya berada pada kategori "Sedang", $77,78 \%$ atau 21 siswa yang minatnya berada pada kategori "Tinggi" dan tidak terdapat siswa yang berada pada kategori "Rendah".

Analisis angket penguatan (Satisfaction) siswa pada siklus I dengan menggunakan skala Likert sebagai berikut :
Tabel 9. Distribusi Frekuensi dan Persentase Angket Penguatan (Satisfaction)

\begin{tabular}{|c|l|c|c|}
\hline Skor dalam \% & Kategori & f & Persentase (\%) \\
\hline $0 \%-33,33 \%$ & Rendah & 0 & $0 \%$ \\
$33,34 \%-66,67 \%$ & Sedang & 3 & $11,11 \%$ \\
$66,68 \%-100 \%$ & Tinggi & 24 & $88,89 \%$ \\
\hline \multicolumn{2}{|c|}{ Jumlah } & 27 & 100 \\
\hline
\end{tabular}

Berdasarkan Tabel 9. dapat disimpulkan bahwa dari 27 orang siswa yang menjadi subjek penelitian $11,11 \%$ atau 3 siswa yang penguatannya berada pada ketegori "Sedang”, 88,89\% atau 24 siswa yang penguatannya berada pada kategori "Tinggi" dan tidak terdapat siswa yang berada pada kategori "Rendah".

2) Deskripsi Pelaksanaan Tindakan Siklus II

Perencanaan pelaksanaan tindakan pada siklus II sama dengan siklus I dengan materi lingkaran tetapi submateri yang berbeda setiap pertemuan.

Hasil tes siklus II siswa kelas VIIIA SMP Negeri 1 Bontonompo dianalisis secara deskriptif sebagai berikut:

$$
\bar{x}=\frac{\sum_{i=1}^{n} x_{i}}{n}=\frac{2065}{27}=76,48
$$

Tabel 10. Statistik Skor Hasil Belajar Matematika Siswa Kelas VIIIA SMP Negeri 1

Bontonompo pada Siklus II

\begin{tabular}{|c|c|c|}
\hline No. & STATISTIK & NILAI \\
STATISTIK \\
\hline 1 & Subjek Penelitian & 27 \\
2 & Skor Ideal & 100 \\
3 & Skor Maksimum & 100 \\
4 & Skor Minimum & 38 \\
5 & Rentang Skor & 62 \\
6 & Skor Rata-rata & 76,48 \\
7 & Standar Deviasi & 17,363 \\
\hline
\end{tabular}


Tabel 10. menunjukkan bahwa skor rata-rata kemampuan siswa dalam pelajaran matematika, setelah diterpkan pembelajaran dengan model ARIAS yang diperoleh pada siklus II adalah rata-rata 76,48 dari skor ideal yang mungkin tercapai 100. Secara individual skor yang dicapai siswa dari skor terendah 38 sampai skor tertinggi 100 dengan skor yang mungkin tercapai dari 0 sampai 100.

Skor hasil tes dikategorikan berdasarkan ketuntasan belajar siswa pada tes akhir siklus II sebagai berikut:

Tabel 11. Deskripsi Ketuntasan Belajar Matematika Siswa Kelas VIIIA SMP Negeri 1

Bontonompo pada Tes Siklus II

\begin{tabular}{|c|c|c|c|}
\hline Skor & Kategori & Frekuensi & $\begin{array}{c}\text { Persentase } \\
(\%)\end{array}$ \\
\hline $0-71$ & $\begin{array}{c}\text { Tidak } \\
\text { Tuntas }\end{array}$ & 6 & 22 \\
\hline $72-100$ & Tuntas & 21 & 78 \\
\hline \multicolumn{2}{|c|}{ Jumlah } & 27 & 100 \\
\hline
\end{tabular}

Tabel 11. menunjukkan bahwa $22 \%$ atau 6 siswa termasuk dalam kategori belum tuntas dan $78 \%$ atau 21 orang dalam kategori tuntas. Jika dianalisis sesuai indikator keberhasilan tindakan untuk skor hasil belajar, pada siklus II skor hasil belajar mencapai ketuntasan baik secara individual maupun klasikal. Karena skor hasil belajar siswa pada siklus II yang berada di atas nilai KKM atau dalam kategori TUNTAS lebih dari $75 \%$ yakni $78 \%$. Dari hasil ini dapat dinyatakan bahwa ketuntasan belajar secara klasikal tercapai.

Keterlaksanaan pembelajaran yang diobservasi adalah aktivitas guru dalam mengelola pembelajaran dengan menerapkan model pembelajaran ARIAS yang mengacu pada RPP sebagai berikut:
Tabel 12. Persentase Keterlaksanaan Model Pembelajaran ARIAS

\begin{tabular}{|c|c|c|c|}
\hline $\begin{array}{c}\text { Pertemuan } \\
\text { Ke- }\end{array}$ & Nilai & $\begin{array}{c}\text { Persentase } \\
(\%)\end{array}$ & Kriteria \\
\hline 6 & 12 & 92,31 & Sangat Baik \\
\hline 7 & 12 & 92,31 & Sangat Baik \\
\hline 8 & 13 & 100 & Sangat Baik \\
\hline
\end{tabular}

Pada Tabel 12. di atas secara keseluruhan pembelajaran dengan menggunakan model pembelajaran ARIAS berada pada kriteria sangat baik pada pertemuan pertama hingga keempat. Berdasarkan hal tersebut, maka dapat disimpulkan bahwa proses pembelajaran yang dilaksanakan pada kelas yang diajar dengan menerapkan model pembelajaran ARIAS terlaksana dan berada pada kategori sangat baik.

Analisis angket percaya diri (Assurance) siswa pada siklus II dengan menggunakan skala Likert sebagai berikut :

Tabel 13. Distribusi Frekuensi dan Persentase Angket Percaya Diri (Assurance)

\begin{tabular}{|c|l|c|c|}
\hline Skor dalam $\%$ & Kategori & Frekuensi & $\begin{array}{c}\text { Persentase } \\
(\%)\end{array}$ \\
\hline $0 \%-33,33 \%$ & Rendah & 0 & $0 \%$ \\
$33,34 \%-66,67 \%$ & Sedang & 1 & $3,7 \%$ \\
$66,68 \%-100 \%$ & Tinggi & 26 & $96,3 \%$ \\
\hline \multicolumn{2}{|c|}{ Jumlah } & 27 & 100 \\
\hline
\end{tabular}

Berdasarkan Tabel 13. dapat disimpulkan bahwa dari 27 orang siswa yang menjadi subjek penelitian 3,7\% atau 1 siswa yang percaya dirinya berada pada ketegori "Sedang", 96,3\% atau 26 siswa yang percaya dirinya berada pada kategori "Tinggi", dan tidak terdapat siswa yang berada pada kategori "Rendah".

Analisis angket minat (Interest) siswa pada siklus II dengan menggunakan skala Likert sebagai berikut : 
Tabel 14. Distribusi Frekuensi dan Persentase Angket Minat (Interest)

\begin{tabular}{|c|l|c|c|}
\hline Skor dalam $\%$ & Kategori & $\mathrm{f}$ & $\begin{array}{c}\text { Persentase } \\
(\%)\end{array}$ \\
\hline $0 \%-33,33 \%$ & Rendah & 0 & $0 \%$ \\
$33,34 \%-66,67 \%$ & Sedang & 3 & $11,11 \%$ \\
$66,68 \%-100 \%$ & Tinggi & 24 & $88,89 \%$ \\
\hline \multicolumn{2}{|c|}{ Jumlah } & 27 & 100 \\
\hline
\end{tabular}

Berdasarkan Tabel 14. dapat disimpulkan bahwa dari 27 orang siswa yang menjadi subjek penelitian $11,11 \%$ atau 3 siswa yang minatnya berada pada kategori "Sedang", 88,89\% atau 24 siswa yang minatnya berada pada kategori "Tinggi" dan tidak terdapat siswa yang berada pada kategori "Rendah".

Analisis angket penguatan (Satisfaction) siswa pada siklus II dengan menggunakan skala Likert sebagai berikut :

Tabel 15. Distribusi Frekuensi dan Persentase Angket Penguatan (Satisfaction)

\begin{tabular}{|c|l|c|c|}
\hline Skor dalam $\%$ & Kategori & Frekuensi & $\begin{array}{c}\text { Persentase } \\
(\%)\end{array}$ \\
\hline $0 \%-33,33 \%$ & Rendah & 0 & $0 \%$ \\
$33,34 \%-66,67 \%$ & Sedang & 1 & $3,7 \%$ \\
$66,68 \%-100 \%$ & Tinggi & 26 & $96,3 \%$ \\
\hline \multicolumn{2}{|c|}{ Jumlah } & 27 & 100 \\
\hline
\end{tabular}

Berdasarkan Tabel 15. dapat disimpulkan bahwa dari 27 orang siswa yang menjadi subjek penelitian $3,7 \%$ atau 1 siswa yang penguatannya berada pada ketegori "Sedang", 96,3\% atau 26 siswa yang penguatannya berada pada kategori "Tinggi" dan tidak terdapat siswa yang berada pada kategori "Rendah".

Untuk melihat peningkatan hasil belajar siswa kelas VIII A SMP Negeri 1 Bontonompo pada pelajaran matematika melalui model pembelajaran ARIAS dalam setiap siklus tercatat sebagai berikut:
Tabel 16. Peningkatan Skor Hasil Belajar Siswa Pada Setiap Siklus

\begin{tabular}{|c|c|c|c|c|c|}
\hline \multirow{2}{*}{ Siklus } & \multicolumn{2}{|c|}{ Skor Perolehan Siswa } & \multicolumn{2}{c|}{ Ketuntasan } \\
\cline { 2 - 6 } & Maks & Min & $\begin{array}{c}\text { Rata- } \\
\text { Rata }\end{array}$ & Tuntas & $\begin{array}{c}\text { Tidak } \\
\text { Tuntas }\end{array}$ \\
\hline $\begin{array}{c}\text { Siklus } \\
\text { I }\end{array}$ & 96 & 32 & 54,67 & 7 & 20 \\
\hline $\begin{array}{c}\text { Siklus } \\
\text { II }\end{array}$ & 100 & 38 & 76,48 & 21 & 6 \\
\hline
\end{tabular}

Untuk percaya diri (Assurance) siswa yang di peroleh dengan memberikan angket dari pra tindakan dan di akhir siklus I dan siklus II sebagai berikut:

Tabel 17. Statistik Skor Percaya Diri (Assurance)

\begin{tabular}{|c|c|c|c|c|}
\hline \multirow{2}{*}{ Skor } & \multirow{2}{*}{ Kategori } & \multicolumn{3}{|c|}{ Persentase (\%) } \\
\cline { 3 - 5 } & & $\begin{array}{c}\text { Pra } \\
\text { Tindakan }\end{array}$ & $\begin{array}{c}\text { Siklus } \\
\text { I }\end{array}$ & $\begin{array}{c}\text { Siklus } \\
\text { II }\end{array}$ \\
\hline $0 \%-33,33 \%$ & Rendah & 0 & 0 & 0 \\
$33,34 \%-66,67 \%$ & Sedang & 66,67 & 7,41 & 3,7 \\
$66,68 \%-100 \%$ & Tinggi & 33,33 & 92,59 & 96,3 \\
\hline \multicolumn{2}{|c|}{ Jumlah } & 100 & 100 & 100 \\
\hline
\end{tabular}

Untuk minat (Interest) siswa yang di peroleh dengan memberikan angket dari pra tindakan dan di akhir siklus I dan siklus II sebagai berikut:

Tabel 18. Statistik Skor Minat (Interest)

\begin{tabular}{|c|c|c|c|c|}
\hline \multirow{2}{*}{ Skor } & \multirow{2}{*}{ Kategori } & \multicolumn{3}{|c|}{ Persentase (\%) } \\
\cline { 3 - 5 } & & $\begin{array}{c}\text { Pra } \\
\text { Tindakan }\end{array}$ & $\begin{array}{c}\text { Siklus } \\
\text { I }\end{array}$ & $\begin{array}{c}\text { Siklus } \\
\text { II }\end{array}$ \\
\hline $0 \%-33,33 \%$ & Rendah & 0 & 0 & 0 \\
$33,34 \%-66,67 \%$ & Sedang & 55,56 & 22,22 & 11,11 \\
$66,68 \%-100 \%$ & Tinggi & 44,44 & 77,78 & 88,89 \\
\hline \multicolumn{2}{|c|}{ Jumlah } & 100 & 100 & 100 \\
\hline
\end{tabular}

\section{Untuk penguatan (Satisfaction)} siswa yang di peroleh dengan memberikan angket dari pra tindakan dan di akhir siklus I dan siklus II sebagai berikut: 
Tabel 19. Statistik Skor Penguatan

(Satisfaction)

\begin{tabular}{|c|c|c|c|c|}
\hline \multirow{2}{*}{ Skor } & \multirow{2}{*}{ Kategori } & \multicolumn{3}{|c|}{ Persentase (\%) } \\
\cline { 3 - 5 } & & $\begin{array}{c}\text { Pra } \\
\text { Tindakan }\end{array}$ & $\begin{array}{c}\text { Siklus } \\
\text { I }\end{array}$ & $\begin{array}{c}\text { Siklus } \\
\text { II }\end{array}$ \\
\hline $0 \%-33,33 \%$ & Rendah & 0 & 0 & 0 \\
$33,34 \%-66,67 \%$ & Sedang & 40,74 & 11,11 & 3,71 \\
$66,68 \%-100 \%$ & Tinggi & 59,26 & 88,89 & 96,29 \\
\hline \multicolumn{2}{|c|}{ Jumlah } & 100 & 100 & 100 \\
\hline
\end{tabular}

Dengan demikian penerapan model pembelajaran ARIAS (Assurance, Relevance, Interest, Assessment, and Satisfaction) merupakan salah satu model pembelajaran yang dapat meningkatkan aktivitas siswa dan hasil belajar matematika kelas VIII A SMP Negeri 1 Bontonompo.

\section{KESIMPULAN}

Berdasarkan deskripsi data dan pembahasan, dapat disimpulkan bahwa Model pembelajaran ARIAS dalam proses pembelajaran matematika terkhusus pada tiga komponen yakni percaya diri (Assurance), minat (Interest) dan penguatan (Satisfaction) mengalami peningkatan presentasi skor sesuai dengan aspek yang diteliti dari pra tindakan, siklus I sampai dengan siklus II dan berada pada kategori tinggi yaitu $66,68 \%-100 \%$.

Aktivitas siswa dalam pembelajaran matematika melalui model pembelajaran ARIAS pada lembar observasi berdasarkan aspek yang diteliti yakni siswa semakin menumbuhkan rasa percaya diri (Assurance), siswa mengetahui tujuan dan manfaat dari pembelajaran serta dapat mengaplikasikannya dalam kehidupan sehari-hari (Relevance), meningkatnya minat siswa belajar matematika yang diajarkan (Interest) hal ini ditandai dengan siswa terlibat aktif dalam menjawab soal dan antusias dalam menyelesaikan LKS, siswa mempresentasikan hasil penyelesaian LKS dan adanya peningkatan skor hasil belajar siswa dalam pembelajaran matematika (Assessment), serta siswa aktif menyimpulkan materi dan memberikan penghargaan kepada temannya yang telah mempresentasikan hasilnya (Satisfaction).

Aktivitas guru dalam pembelajaran matematika melalui model pembelajaran ARIAS pada lembar observasi berdasarkan aspek yang diteliti yakni guru meningkatkan percaya diri siswa (Assurance) dengan melaksanakan proses pembelajaran yang baik serta menyampaikan tujuan pembelajaran, guru mengarahkan siswa untuk memberikan contoh berdasarkan materi yang diajarkan yang berhubungan dengan kehidupan seharihari (Relevance), guru membangkitkan minat siswa selama proses pembelajaran dan melakukan pengarahan atau bimbingan (Interest), guru mengecek pemahaman dengan mempersilahkan siswa mempresentasikan hasil LKS dan memberikan tes hasil belajar di setiap akhir siklus (Assessment), serta guru menanamkan rasa bangga pada siswa dan memberikan pujian, reword atau nilai tambah kepada siswa (Satisfaction).

Suasana kelas dalam pembelajaran matematika melalui model pembelajaran ARIAS pada lembar observasi berdasarkan aspek yang diteliti yakni interaksi antar siswa mengalami peningkatan yang baik dari setiap pertemuannya dimana siswa terlibat aktif dan lebih percaya dalam menyampaikan ide/pendapat baik secara 
individu maupun kelompok, siswa aktif dalam melakukan tanya jawab kepada guru, fasilitas kelas yang tersedia kurang memadai akan tetapi tidak mengganggu proses pembelajaran.

Model pembelajaran ARIAS dalam proses pembelajaran matematika dapat meningkatkan hasil belajar matematika siswa kelas VIII A SMP Negeri 1 Bontonompo. Hal ini berdasarkan dengan peningkatan skor rata-rata siswa dari sebelum menerapkan model pembelajaran ARIAS dan setelah menerapkan model pembelajaran ARIAS pada siklus I yaitu 54,67 dengan persentase ketuntasan $26 \%$ menjadi rata-rata 76,48 dengan persentase ketuntasan $78 \%$ pada siklus II.

\section{DAFTAR PUSTAKA}

Hendriyani, I. (2010). Pengaruh Model Pembelajaran Tandur Terhadap Hasil Belajar Fisika Siswa (Universitas Islam Negeri Syarif Hidayatullah).

Masykur, M., \& Abdul Halim, F.
(2009). Mathematical Intelligence: Cara Cerdas Melatih Otak dan Menanggulangi Kesulitan Belajar (2nd ed.). Jogjakarta: Ar-Ruzz Media.

Rahman, M., \& Amri, S. (2014). Model Pembelajaran ARIAS Terintegratif (1st ed.; U. Athelia Kurniati, Ed.). Jakarta: PT. Prestasi Pustakaraya.

Sthyawati, P. (2011). Penerapan Model Pembelajaran ARIAS (Assurance, Relevance, Interest, Assessment, dan Satisfaction) Untuk Meningkatkan Aktivitas Belajar Matematika Siswa. Universitas Islam Negeri Syarif Hidayatullah.

Suerman, E., Turmudi, Suryadi, D., Herman, T., Suhendra, Prabawanto, S., ... Rohyati, A. (2003). Strategi Pembelajaran Matematika Kontemporer. Bandung: JICAUniversitas Pendidikan Indonesia.

Suprihatingrum, J. (2013). Strategi Pembelajaran Teori dan Aplikasi. Jogjakarta: Ar-Ruzz Media.

Wiriaatmadja, R. (2006). Metode Penelitian Tindakan Kelas Untuk Meningkatkan Kinerja Guru dan Dosen. Bandung: Remaja Rosdakarya. 